\title{
Motivos filo-esópicos en el Midrás. Fábulas y anécdotas de rabinos en Levítico Rabbá 22,4
}

\author{
Lorena Miralles Maciá * \\ Universidad de Granada
}

El pasaje de LvR 22,4 combina armoniosamente una serie de fábulas con algunos episodios de la vida de ciertos rabinos. Estos relatos comparten un mismo contexto y una misma temática, ya que están relacionados con la observación de la naturaleza y sobre todo del mundo animal. Aunque no es posible afirmar con seguridad si el origen de las fábulas se halla en las tradiciones esópicas, se observan claros paralelos entre las imágenes del Midrás y las de las colecciones de época helenística-romana que han llegado hasta nuestros días. Por tanto, el presente estudio tiene una doble finalidad: por un lado, el análisis de las fábulas y su vinculación con los motivos esópicos y, por otro, ofrecer un valioso ejemplo de cómo se conjugan estos relatos con las anécdotas de los sabios a través de los recursos propios de la literatura rabínica.

Palabras ClaVE: Levítico Rabbá; fábulas; anécdotas de rabinos; tradición esópica.

PHILO-AESOPIAN MOTIFS IN THE MIDRASH: FABLES AND SAGES' ANECDOTES IN LEVITICUS RABBAH.- The text of LvR 22:4 collects some fables and the Rabbis' vital experiences, bringing them together harmoniously. These stories share the same context and theme, because they both are related to the observation of the nature and especially to the world of the animals. Although it is not possible to ascertain whether the origin of the fables lies in the Aesopian tradition, clear parallels are observed between the images of the Midrash and those of the Roman-Hellenistic collections that have come down to us. Therefore, the aim of this study is twofold: on the one hand, to analyse the fables and their links with the Aesopian motifs and, on the other, to offer a valuable example of how these tales are perfectly combined with the Sages' anecdotes by means of the Rabbinic literary devices.

KeYwords: Leviticus Rabba; Fables; Sages' anecdotes; Aesopian Tradition.

Entre las distintas colecciones de fábulas que nos han llegado de la Antigüedad el ejemplo más significativo es el de los relatos esópicos, que han sido transmitidos en diferentes lenguas y formas literarias (prosa o verso) y que siguen gozando de plena actualidad. Si bien no podemos ir más allá de lo que nos cuenta la leyenda acerca de la vida y obra original de Esopo, es indudable

\footnotetext{
* lorenamm@ugr.es
} 
que las colecciones recogidas y/o compuestas bajo su autoría disfrutaron de gran fama. Esto permitió su difusión de manera más o menos sistemática hasta la Edad Media y después hasta nuestros días. En estas colecciones tuvieron cabida tanto los motivos de la sabiduría popular del mundo helenístico-romano como las fábulas de los pueblos del entorno. Podemos suponer entonces que muchas de las narraciones breves que hoy se catalogan como «fábulas esópicas» tienen su origen en una tradición que se remonta a Asia Menor, Egipto y sobre todo a la India. Al mismo tiempo, este corpus sirvió como fuente de inspiración para las grandes composiciones medievales en árabe, hebreo, latín, lenguas romances, germánicas, etc.

Aunque la supuesta obra original del legendario Esopo se perdió (la cual dataría del s. VI a.C.) y también la recopilación de Demetrio de Fáleron, Aesopica (s. III a.C.), nos han llegado al menos tres colecciones de fábulas esópicas cuya fecha es anterior a los primeros midrašim judíos (a partir del s. III d.C.): la recensión Augustana en prosa (cuyo núcleo inicial se sitúa en el s. I a.C., o incluso antes y cuya forma definitiva puede datar de los ss. IV-V d.C.) y los trabajos en verso en griego y latín respectivamente de Babrio (s. II a.C.) y Fedro (ss. I a.C - I d.C. $)^{1}$. Además, es posible que otras fábulas y otros motivos, pertenecientes incluso a un corpus muy antiguo, se hubieran seguido transmitiendo sólo de forma oral y hubieran sido incorporados a la literatura escrita en fecha muy posterior. En el presente estudio se hace referencia con las expresiones «fábulas esópicas» o «motivos esópicos» (nunca «fábulas de Esopo») a esa tradición que arranca en el Oriente Próximo, Egipto, la India y Grecia, que confluye en el mundo helenístico-romano bajo la autoría de un Esopo legendario y que posteriormente es transmitida a otros pueblos ${ }^{2}$.

${ }^{1}$ Véase L. Miralles Maciá, «The fable of 'the Middle-Aged Man with Two Wifes': from the Aesopian Motif to the Babylonian Talmud Version in b. B. Qam. 60b», JSJ 39 (2008), págs. 268-270 y la bibliografía de las siguientes dos notas. Los corpora de textos en griego y latín se pueden consultar en B. E. Perry, Aesopica: A Series of Texts Relating to Aesop or Ascribed to Him of Closely Connected with the Literary Tradition that Bears His Name (Urbana 1952); B. E. Perry, Babrius and Phaedrus (Cambridge, Mass. 1965).

${ }^{2}$ Existen numerosas colecciones y traducciones de fábulas esópicas, pero para facilitar la localización de éstas sin recargar el texto cito por los índices de PERRY, Aesopica, y la página web de L. GibBs: Aesopica: Aesop's Fables in English, Latin \& Greek (http://mythfolklore.net/ aesopica/index.htm). Sobre las distintas tradiciones donde aparecen las fábulas griegas y latinas se debe consultar la completísima obra de Fr. Rodríguez Adrados, Historia de la fábula grecolatina, vol. 3: Inventario y documentación de la fábula greco-latina (Madrid 1987); sobre todo su edición en inglés revisada y aumentada: History of the Graeco-Latin Fable. Vol. 3: Inventory and Documentation of the Graeco-Latin Fable (trans. L. A. Ray, F. RoJAS DEL Canto. Supplemented and Edited by the Author and Gert-Jan van DiJK, Leiden-Boston 2003). 
Las fábulas esópicas nunca dejaron de pertenecer al ámbito de la oralidad como parte de la sabiduría y el imaginario populares. Sus temas continuaron siendo incorporados y adaptados a nuevos contextos siempre que surgía la necesidad de aportar ejemplos didácticos. En este sentido, los motivos de la tradición esópica tuvieron muy buena acogida en los círculos rabínicos, según nos lo demuestran las numerosas fábulas que el Midrás y el Talmud nos han transmitido en forma de parábolas (mašal, matla') y casos particulares (ma 'aśé, 'ubda') ${ }^{3}$. Asimismo, la literatura rabínica tenía el terreno abonado para dar cabida a este género sapiencial:

(a) Los contactos de Israel con los pueblos del Oriente Próximo y Egipto y mucho después con las tradiciones indias dejaron su impronta en su literatura sapiencial, cuyos temas e imágenes tienen a menudo un claro paralelo entre sí ${ }^{4}$.

(b) En la Biblia Hebrea ya encontramos algunas narraciones breves con un estilo similar al de las fábulas esópicas, como por ejemplo la historia de los árboles que querían coronar un rey entre ellos $(\mathrm{Ju} 9,8-15)^{5}$.

(c) En época del Segundo Templo apareció una importantísima literatura sapiencial, que bebía de las tradiciones helenísticas en sentido amplio y que, sin entrar a formar parte de la Biblia Hebrea, caló profundamente en la tradición judía y después rabínica.

(d) La tradición rabínica ya disponía de los recursos necesarios para adaptar las fábulas esópicas a sus desarrollos hermenéuticos a través de las parábolas y los casos particulares.

A grandes rasgos la fábula esópica se define como un cuento breve protagonizado por animales, plantas, objetos inanimados, seres humanos o dioses que

${ }^{3}$ Véase por ejemplo la lista de J. JACOBS, «Aesop's Fables Among the Jews», Jewish Encyclopedia (www.jewishencyclopedia.com); H. Schwarzbaum, «Talmudic-Midrashic Affinities of some Aesopic Fables», en ed. H. A. Fischel, Essays in Greco-Roman and Related Talmudic Literature (New York 1977), págs. 425-442; Sh. Friedman, «The Talmudic Proverb in Its Cultural Setting» [heb.], JSIJ 2 (2003), págs. 25-82. Sobre los motivos del folklore en los textos rabínicos véase D. Neuman, Motif-Index of Talmudic-Midrashic Literature (PhD Diss., Bloomington, IN 1954), sobre todo los relativos a los animales págs. 202-250, y C. Thoma - S. Lauer, Die Gleichnisse der Rabbinen, 4 vols. (Bern 1986-2000).

${ }^{4}$ Para las fábulas egipcias véase E. BRunNER-Traut, Altägyptische Tiergeschichte und Fabel: Gestalt und Strahlkraft (Darmstadt 1984), las de Babilonia: W. G. LAMBERT, Babylonian Wisdom Literature (Oxford 1960), págs. 175ss. La colección más representativa de la India es la conocida con el nombre de Panchatantra (véase la n. 19 al final).

${ }^{5}$ Este relato fue incorporado desde la Edad Media a las colecciones de fábulas esópicas: Perry 262; GibBs 26. 
llevan a cabo una acción o tienen un determinado comportamiento cuya consecuencia se traduce en una enseñanza específica. Ésta podía deducirse de la propia fábula o bien aparecer en forma de sentencia breve al inicio o al final de la historia. Partiendo de la presente definición, podemos suponer que ni el Midrás ni el Talmud encontraron grandes impedimentos a la hora de amoldar la fábula esópica al esquema de la parábola rabínica (mašal, matla'), compuesta por la propia narración y su aplicación (nimšal), y al del caso particular (ma 'aśé, 'ubda'), del que se deriva una regla o principio con el que se justifica una opinión ${ }^{6}$.

La literatura rabínica se sirvió de la tradición esópica de dos maneras. (1) Por un lado, algunas fábulas fueron incorporadas al corpus literario rabínico con muy pocas variantes, de modo que se puede leer sinópticamente el mašal o el ma 'aśe frente a la fábula (en griego y/o latín). (2) Por otro, se hallan referencias o reelaboraciones de fábulas en los textos midrásicos y talmúdicos, en los que se intuye un sustrato de la tradición esópica. En relación con estos segundos casos no podemos hablar de «fábulas esópicas» tal y como nos han llegado a través de las colecciones, sino de «motivos esópicos». Es en este sentido como se va a abordar el presente estudio.

\section{El CONTEXTO De LvR 22,4}

En Levítico Rabbá (= LvR), obra cuya composición final se sitúa probablemente en la Palestina de los Ss. IV-V d.C., encontramos un fragmento en el que aparecen varios motivos esópicos (algunos bastante reelaborados). Se trata del pasaje de LvR 22,4, en el que la interpretación rabínica de un versículo se justifica a través de los episodios protagonizados por diferentes maestros o por medio de ejemplos que podemos catalogar de «fábulas». Estos relatos breves, la mayoría transmitidos en arameo, han sido introducidos en la narración de la siguiente manera:

(a) Si es una fábula, se indica con la expresión aramea עובדא הוה ב... ("un hecho / una historia sucedió en relación con') que aquí podemos interpretar como 'érase una vez';

(b) sólo en un caso aparece la fórmula aramea חד זמן ('en una ocasión') en conexión con el relato sobre un rabino que acaba interviniendo en la propia fábula;

(c) si se refiere a una anécdota relacionada con un rabino, se especifica su nombre, sin utilizar ningún tipo de fórmula;

${ }^{6}$ Para el caso del mašal véase Miralles Maciá, «The Fable», págs. 270-272 y la bibliografía allí citada. 
(d) una excepción es la última narración donde aparece la fórmula .... מעשה ב, que normalmente es considerada la equivalente hebrea de עובדא הוה ב..., pero que aquí se utiliza para introducir un episodio distinto de los anteriores.

La parašá de LvR 22, que comenta Lv 17,3: «Todo hombre de la casa de Israel que inmole un toro, un cordero o una cabra en el campamento, o que lo inmole fuera del campamento», comienza poniendo en conexión este versículo con Qo 5,8 en su interpretación rabínica: «Lo superfluo de la tierra está [incluido también] entre todas las cosas» ${ }^{7}$. Para justificar este versículo se enumeran una serie de casos: las bagatelas del mundo y las incluidas en la Revelación (LvR 22,1), algunos insectos como moscas, pulgas y mosquitos (LvR 22,2); y en LvR 22,3 se ofrece una interpretación de Qo 5,8 vinculada a las palabras que Dios les dirigió a los profetas avisándolos de que, si ellos no estaban dispuestos a cumplir con Sus mandatos, se serviría de animales como la serpiente, la rana, el escorpión, el mosquito. Como prueba de que éstos están destinados a infligir al hombre los castigos por sus fechorías, se cuenta el episodio del malvado Tito, cuya muerte la causó el mosquito del vino que se le coló por la nariz, le llegó hasta el cerebro y creció hasta alcanzar el tamaño de una paloma. En medio de este relato se incluye una referencia a las aguas como instrumento punitivo para los malvados, relacionada con la tormenta a la que Tito sobrevivió camino de Roma.

El presente contexto, donde predominan las referencias al mundo animal, favoreció la inclusión de fábulas y anécdotas de rabinos en LvR 22,4. Éstas gozaron de gran popularidad entre los midrašim, ya que no sólo tenemos como paralelo de todo el pasaje el texto de QoR 5,5 (a Qo 5,8), sino que algunos de los relatos también fueron recogidos por GnR 10,7; NmR 18,22; Tanj Huqqat $1^{8}$.

\section{Motivos EsóPICOS EN LvR 22,4}

En la mayoría de manuscritos el párrafo se inicia con la fórmula rabínica 'otra interpretación' (דבר אחר) y la cita de Qo 5,8. En el contexto de la fábula, este versículo (que formalmente es el proemio de la homilía de Lv 17,3) desempeña también la función de moraleja (sentencia breve que resume la enseñanza

7 יתרון, que significa 'ventaja, provecho', se puede interpretar según el contexto del Midrás como «lo que sobra» (M. JASTROw, Dictionary of the Targumim, the Talmud Babli and Yerushalmi, and the Midrashic Literature [London - New York 1903], s.v.), demostrando que incluso lo que se considera superfluo también tiene una razón para existir.

${ }^{8}$ El pasaje completo de QoR se puede consultar en M. ${ }^{a}$ C. Motos López, Midrás Qohélet Rabbah. Las vanidades del mundo. Comentario rabínico al Eclesiastés (Estella 2001), págs. 258ss. 
desprendida de la narración). En este caso precede a la historia (promicio) y pone de manifiesto que la existencia de todo lo que se encuentra sobre la tierra, por insignificante y despreciable que parezca, tiene su provecho, ya que está destinado a cumplir con los mandatos divinos.

Los relatos se presentan en el mismo orden que en la edición de Margulies, indicando en cada caso si se trata de una fábula o de un episodio en la vida de un rabino. El texto base de esta edición es el manuscrito de Londres, pero tengo en cuenta además las variantes y añadidos más significativos de otros manuscritos (principalmente el de Múnich) y sobre todo de la Editio Princeps (= EP), puesto que son importantes para iluminar y aclarar la interpretación del texto .

\subsection{La fábula de la rana y el escorpión}

En la actualidad una de las fábulas más populares es, sin duda, la del escorpión que le pide a una rana que le pase el río sobre su espalda. La rana acepta cargar con él, pero a mitad de río el escorpión le pica, causando la muerte de ambos: la de ella por envenenamiento y la de él porque se acaba ahogando. Antes de morir, la rana le pregunta por qué lo ha hecho y éste le contesta que está en su propia naturaleza el actuar asi $1^{10}$.

Con frecuencia esta fábula ha sido erróneamente atribuida a Esopo. Sin embargo, aunque no pertenecía al corpus de las grandes colecciones griegas y latinas que nos han llegado, no debemos descartarla como parte de la tradición esópica en el sentido más amplio, ya que o bien sólo fue transmitida oralmente de un pueblo a otro, o su origen se encuentra en un relato antiquísimo: en la fábula esópica del ratón y la rana (Perry 384 ; Gibbs 139$)^{11}$. En ésta se narra cómo un ratón le pide a una rana que le cruce un río. Con una cuerda se ata la pata del ratón a la suya y nadando llega hasta la mitad. Allí la rana se sumerge intencio-

${ }^{9}$ M. Margulies, Midrash Wayyikra Rabbah. A Critical Edition Based on Manuscripts and Genizah Fragments with Variants and Notes (5 vols., Jerusalem, 1953-1960). Para ver los manuscritos completos: Ch. MıLIKоwsKY, http://www.biu.ac.il/JS/midrash/VR/editionData.htm (2004).

${ }^{10}$ En una versión india interviene en la fábula una tortuga en lugar de una rana; véase M. Burrows Danton, «The Scorpion and the Tortoise», The Tortoise and the Geese and other Fables of Bidpai (Boston-New York 1908), recogido en The Baldwin Online Children's Project, Bringing Yerterday's Classics to Today's Children, Yesterday's Classics LLC (http://www.biu.ac.il/JS/ midrash/VR/editionData.htmhttp://www.mainlesson.com/displayauthor.php?author=dutton, 2000-2008).

11 Por ejemplo, JACOBS («Aesop’s Fables») cita este relato en conexión con bNed 41a. 
nadamente y el ratón se ahoga, de manera que su cuerpo queda flotando sobre el agua. Entonces un milano que volaba por la zona ve el cuerpo del ratón y lo atrapa, llevándose la rana atada a la pata. Así, el cadáver del ratón y la malvada rana se convierten en comida para el milano ${ }^{12}$.

La versión aramea de LvR, que tiene como paralelos arameos GnR 10,7 y QoR 5,5 y hebreos NmR 18,22 y Tanj Huqqat $1^{13}$, nos sorprende por dos motivos: (1) los protagonistas son una rana y un escorpión, como en la fábula que hoy en día circula y no como en la esópica, y (2) el final no se resuelve con la muerte de los animales, sino con la de un hombre al que le pica el escorpión.

Otra interpretación de Lo superfluo de la tierra (Qo 5,8). En relación con este [versículo] dijo R. Tanjuma [que] R. Menajmá, R. Berekyá, R. Jelbó y R. Ajá contaron [la siguiente fábula]:

Érase una vez (עובדא הוה ב...) un hombre que estaba de pie a la orilla del río ${ }^{14}$ y vio una rana cargando con un escorpión para cruzar el río. Exclamó (el hombre): «iÉste está destinado a cumplir Su misión (la de Dios)!». (La rana) le cruzó el río y (el escorpión) fue a llevar a cabo su misión y [entonces] (la rana) vino a devolverlo a su lugar.

(EP añade en hebreo:) Y se escuchó un grito de lamento en la ciudad: «iA fulano lo ha mordido un escorpión y ha muerto!». ${ }^{15}$

Evidentemente las diferencias entre la fábula esópica y el relato del Midrás son notables, en especial en la función que desempeñan los personajes: mientras que en la tradición esópica el mal infligido por la rana al ratón le es devuelto por medio del milano, en el Midrás la rana y el escorpión son enviados a cumplir la voluntad divina acabando con la vida de un hombre ${ }^{16}$. De aquí se desprende la moraleja que encierra la interpretación rabínica de Qo 5,8.

${ }^{12}$ Más elaborada en GibBs 140. La fábula aparece en la tradición india (Batrachomyomachia) y también en la egipcia; véase H. Schwarzbaum, The Mishle Shu'alim (Fox Fables) of Rabbi Berechiah ha-Nakdan. A Study in Comparative Folklore and Fable Lore (Kiron 1979), págs. 5-7. Sobre la fábula en la tradición helenístico-romana y medieval véase RodRíGuEz AdRADOS, Inventario y documentación, págs. 274ss. (H 302); pág. 511 (M 312).

${ }^{13}$ En hebreo también en el ms. de Múnich de LvR.

${ }^{14}$ El Jordán según el ms. de Múnich y en las versiones de NmR 18,22, Tanj Huqqat 1.

${ }^{15}$ Estas palabras también aparecen en QoR 5,5 (a QoR 5,8). El ms. de Múnich reproduce la fábula en hebreo introducida por la fórmula ma a séé y atribuida a R. Janán de Séforis.

${ }^{16}$ Estas diferencias han llevado a Schwarzbaum (The Mishle Shu 'alim, pág. 6), con el que no estoy de acuerdo, a negar una conexión entre los relatos. 
No obstante, resultan mucho más significativas sus semejanzas: un mismo escenario, el motivo de la rana arrastrando o cargando con otro animal que no sabe nadar y la participación de un tercer personaje del que depende la resolución de la fábula (de una forma o de otra). Además de estos puntos en común, hay que tener en consideración las siguientes observaciones: (a) una misma fábula puede ser modificada de una tradición a otra según las intenciones de los autores; (b) la finalidad de una determinada fábula, resumida en la moraleja, no es siempre la misma entre las tradiciones ${ }^{17}$; (c) tanto el Midrás como el Talmud son textos que permitieron la adopción de historias populares para iluminar y justificar las opiniones de los rabinos, modificándolas según sus necesidades.

En definitiva, se puede admitir sin dificultad una cierta influencia de la tradición esópica en esta fábula, ya que no es improbable que la imagen de la rana arrastrando a otro animal en un río o en una charca fuera recibida de manera oral y adecuada al contexto midrásico. De hecho, si tuviéramos la certeza de que la fábula circulaba en aquellos tiempos más o menos como hoy la conocemos, este final distinto hubiera causado seguramente un gran impacto en el receptor.

LvR y sus paralelos no son los únicos pasajes donde se menciona este motivo en la literatura rabínica. En un fragmento del Talmud de Babilonia (Ned 41a) se dice que un rabino, Semuel, en una ocasión fue testigo de este hecho.

\subsection{La fábula del segador y la serpiente}

Uno de los motivos más frecuentes en las fábulas es el de la serpiente que intenta acabar con la vida de un hombre. Encontramos numerosos ejemplos en las composiciones de época helenística-romana, cuyo origen se remonta seguramente a las tradiciones del Oriente Próximo, la literatura india y a los primeros relatos esópicos. En las colecciones de fábulas esópicas que datan de este periodo se recogen varias historias relacionadas con el presente motivo, entre las que destaco tres casos ${ }^{18}$ :

(a) El cazador de pájaros y la víbora (Perry 115; Gibbs 138): un cazador de pájaros vio un tordo en un árbol y observándolo fijamente para apresarlo

${ }^{17}$ Un caso muy claro, que aparece en las colecciones esópicas más antiguas y en el Talmud, es el de la fábula del hombre que tenía dos amantes, una joven y otra vieja, cuya finalidad (expresada en la moraleja) va cambiando según la tradición o el contexto que la recoja; véase MirALLES MACiÁ, «The Fable», págs. 272ss.

${ }^{18}$ Un cuarto caso es el del hombre que reanima una víbora con su calor (PERRY 176; GiBBs 440); véase el apartado 2.7. al final. 
pisó una víbora que le mordió. Antes de morir reconoció que, queriendo matar una presa, él mismo se había convertido en una.

(b) El granjero y la serpiente doméstica (Perry 573; Gibbs 74): una serpiente, que vivía en casa de un granjero, iba a comer a su mesa; después de enriquecerse, se enfadó con la serpiente y, atacándola con un hacha, intentó deshacerse de ella. Al perder su fortuna y comprender que ella era la causante de su dicha, intentó recuperar la amistad con la serpiente, pero ella le dijo que no podrían ser amigos hasta que su cicatriz se curara totalmente ${ }^{19}$.

(c) La serpiente que muerde al hijo de un granjero (Perry 51; Gibbs 75): una serpiente que solía rondar la puerta de la casa de un granjero mordió y mató a su hijo. Queriéndose vengar, tomó un hacha e intentó golpearla, pero sólo le cortó la punta de la cola. Por miedo a la venganza, se dispuso a hacer las paces con ella. Sin embargo, ésta le aseguró que su amistad sería imposible, porque cada vez que ella mirara su cola se acordaría de lo sucedido y lo mismo le pasaría a él siempre que viera la tumba de su hijo ${ }^{20}$.

También en la literatura rabínica se recogen fábulas protagonizadas por serpientes ${ }^{21}$. Una de ellas es la que aquí presenta LvR 22,4 en conexión con un ser humano, igual que en los tres relatos esópicos citados anteriormente. La fábula midrásica, transmitida casi toda en arameo y con paralelos en GnR 10,7; NmR 18,22; QoR 5,5; Tanj Ḥuqqat 1, dice así:

R. Pinjás en nombre de R. Yojanán de Séforis [contó la siguiente fábula]:

Érase una vez (עובדא הוה ב...) un hombre que estaba segando en el valle de Bet-Šifá. Vio una planta, la tomó y se hizo una tiara para su cabeza ${ }^{22}$.

${ }^{19}$ Sobre esta fábula y la siguiente en las distintas tradiciones clásica e india véase SchWARZBAUM, The Mishle Shu'alim, págs. 123-137. Las versiones esópicas se pueden leer conjuntamente con la historia india (Panchatantra III 5) en J. JACOBS, Indian Fairy Tales (London-New York 1912), págs. 246-247; en las págs. 112-114 se puede consultar la historia india en traducción inglesa. En traducción alemana véase la de Th. BENFEY (de 1859) recogida en la edición de A. GREITHER, Pancatantra. Die fünf Bücher indischer Lebensweisheit (München 1986), págs. 150-151.

${ }^{20}$ En la literatura rabínica también se hallan varios casos donde una serpiente pretende morder o muerde a una persona. En LvR 20,3 tenemos un ejemplo relacionado con el hijo de un determinado hombre y para otras historias véase H. Schwarzbaum, Studies in Jewish and World Folklore (Berlin 1968), pág. 280.

${ }^{21}$ Véase A. M. Singer, Animals in Rabbinic Teaching: The Fable (New York 1979), págs. 79-88.

${ }^{22}$ M lee en hebreo: «Había una vez (ma'asée) un segador que estaba segando en el valle de Bet-Topaj y cuando llegó la hora de la calina tomó una planta y se la ató a la cabeza». También NmR 18,22 y Tanj Ḥuqqat 1 señala el momento del día. 
[Entonces] pasó una serpiente, a la que golpeó y mató. Pasó un encantador y se quedó mirando la serpiente aquella. Exclamó: «¡Me pregunto quién habrá matado esta serpiente!». Respondió el hombre: «¡Yo la he matado!». Levantó el rostro y vio la planta reelaborada en [forma de] tiara sobre su cabeza. Le dijo: «¡Ciertamente [que] tú la mataste!». Le preguntó: «¿Puedes quitarte esa planta de tu cabeza?». Le respondió: «Sí». Después de quitársela le preguntó: «¿Puedes tocar la serpiente con esta ramita?». Le respondió: «Sí». Justo después de tocar la serpiente se le aflojaron sus miembros.

Es imposible saber si realmente el origen de esta fábula se encuentra entre los relatos esópicos, pero la similitud entre los motivos es innegable: por un lado, un hombre vinculado a las labores del campo quiere matar una serpiente y, por otro, este animal acaba con su vida.

No obstante, la fábula midrásica está mucho más elaborada e incorpora elementos más sofisticados: la planta, el hechicero, la ramita. Además, la forma de resolver la historia es muy ingeniosa, ya que sólo al final podemos comprender la función de los personajes y objetos que intervienen: el segador estaba destinado a morir, la serpiente a matarlo, la tiara con la planta a protegerlo del veneno, el encantador a asegurarse de que esto se llevara a cabo, la ramita a transmitirle el veneno. Todo el tiempo en que el segador lleva sobre su cabeza la tiara, el veneno de la serpiente no hace su efecto, pero cuando el encantador le pide que se la quite y que toque al animal con una ramita, se intoxica y cae muerto ( «se le aflojaron sus miembros»).

El texto no nos dice si este experto (supuestamente conocedor de los designios divinos) había ejercido algún tipo de encantamiento sobre la serpiente. Sin embargo, el razonamiento rabínico así lo pudo entender. La fábula se enmarca en la explicación de Qo 5,8, donde se utiliza la palabra yitron ('lo superfluo, el provecho', entre otras acepciones). En una de las numerosas ocasiones en las que se halla el mismo término en Qohélet se dice: «Si la serpiente muerde falta de encantamiento, ningún 'provecho' (יתרון) obtiene el encantador» (Qo $10,11)^{23}$. No sabemos si la serpiente atacó previamente al segador por influencia de este personaje y su veneno no le causó daño (gracias a la tiara), o bien si sólo lo infectó una vez muerta (cuando él ya no llevaba la planta sobre la cabeza). En cualquier caso, la finalidad es la misma: la serpiente termina con su existencia cumpliendo la voluntad divina.

${ }^{23}$ Véase en LvR 26,2 la excusa que da la serpiente cuando se le pregunta por qué muerde, la cual está basada en este versículo (SINGER, Animals in Rabbinic Teaching, pág. 85). 
2.3. Dos anécdotas protagonizadas por R. Yannay y R. Lazar: los casos de la mordedura de serpiente

Después de la fábula del segador y la serpiente se recogen un par de historias vinculadas a la experiencia vital de dos rabinos, en las que se menciona la muerte de un hombre por una mordedura de serpiente. La primera de ellas ha sido transmitida en una lengua mezcla de hebreo y arameo, y tiene como paralelos GnR 10,7; NmR 18,22; QoR 5,5; Tanj Ḥqqat 1.

R. Yannay estaba sentado estudiando en la puerta de la ciudad y vio una serpiente que venía agitada. [Si] la perseguía por un lado, ella volvía por el otro lado. Exclamó: «¡Ésta está destinada a cumplir Su misión!». En ese momento un rumor se extendió por la ciudad: «i[A] fulano de tal, hijo de mengano, le ha mordido una serpiente y ha muerto!».

R. Yannay comprende de inmediato que, si no es capaz de cazar un animal tan despreciable como una serpiente, Dios la ha elegido para llevar a cabo una empresa. Efectivamente, su deducción se ve confirmada cuando escucha el lamento de los ciudadanos. Sin embargo, frente a la descripción de las circunstancias de R. Yannay, que lo sitúa estudiando en la puerta de la ciudad, el relato no especifica datos tan importantes como la identidad del individuo o las razones divinas para tan aciago destino.

Por el contrario, en el episodio siguiente la historia ofrece más información: el hombre al que le muerde la serpiente es un romano y su muerte le lleva a salvar la vida de R. Lazar. El texto, recogido en arameo, tiene menos paralelos directos que el anterior (GnR 10,7; QoR 5,5), pero el Talmud de Babilonia hace referencia a él en Ber $62 b^{24}$.

R. Lazar estaba sentado defecando en la letrina. Vino un romano [que] lo hizo levantarse y se sentó [en su lugar]. Dijo (el rabino): «iNo es esto en vano!». En ese momento salió una serpiente, lo atacó y mató al romano. Recitó (el rabino) respecto a él [este versículo]: Entregaré al 'hombre' ('adam) en lugar tuyo (Is 43,4), [refiriéndose a:] Entregaré a 'edom' (=al romano) en lugar tuyo.

Desde el principio hasta el fin no falta la ironía en esta anécdota, sobre todo en contraste con el caso anterior, donde R. Yannay estaba realizando una tarea elevadísima. Aquí R. Lazar está en una situación mucho menos distinguida:

${ }^{24}$ Llamándolo Elazar (variante de Lazar), igual que en los paralelos. 
defecando en una letrina. Como el romano le hace levantarse sin haber acabado de hacer sus necesidades corporales, el rabino intuye un motivo divino, que se ve confirmado poco después con la aparición de la serpiente. Finalmente, R. Lazar entona un versículo bíblico que da explicación a lo sucedido: Dios ya había augurado que el romano (Edom) sería entregado a la serpiente en lugar del rabino. La identificación de Edom con Roma (o romano) es común en la literatura rabínica.

Así pues, aunque claramente estos relatos no pertenecen al ámbito de la fabulística, comparten la misma temática del cuento del segador y la serpiente, subrayando la idea de que Dios se sirve de este animal para cumplir Su misión.

\subsection{La anécdota de R. Yisjaq ben Elazar relacionada con el fémur y el emisario imperial}

La siguiente historia, que tampoco es una fábula y que además no está relacionada con la mordedura de una serpiente, tiene también conexión con los casos anteriores, pues comparte rasgos similares: se presenta como la experiencia vivida por un rabino, interviene un romano y hay un agente divino destinado a poner fin a la vida de éste, cuya muerte repercute positivamente sobre la comunidad judía. El texto, recogido principalmente en hebreo con mucha influencia aramea, se encuentra también en GnR 10,7; NmR 18,22; QoR 5,5.

R. Yisjaq ben Elazar se encontraba sobre uno de los diques del mar de Cesarea y vio un fémur que se acercaba rodando y [aunque] él lo apartaba, (el fémur) [continuaba] rodando. Exclamó: «iÉste está destinado a cumplir Su misión!». Después de unos días pasó un emisario (imperial), (el fémur) rodó entre sus piernas, dio un traspié por su causa, cayó y murió. Fueron y lo registraron y encontraron que llevaba documentos desfavorables para los judíos de Cesarea.

Este episodio se enmarca en la misma temática que los casos anteriores, con la diferencia de que el agente divino consiste en un fémur en lugar de en una serpiente. Prueba de ello es que el rabino repite las mismas palabras que en el relato de la serpiente y R. Yannay. Por tanto, el cuento breve del segador y la serpiente y estos tres episodios son un buen ejemplo de cómo el pasaje de LvR 22,4 y sus paralelos combinan de forma armoniosa la fábula con las anécdotas de rabinos. 
2.5. El episodio fabulístico del huerto de R. Simeón ben Jalafta, la hierba y la abubilla

La siguiente historia gira en torno a la figura de R. Simeón ben Jalafta; ha sido transmitida en arameo y sólo tiene un paralelo (QoR 5,5). Se inicia como una anécdota, pero adquiere la categoría de fábula, convirtiendo al rabino en un personaje que interviene en los hechos, en lugar de ser un mero espectador que transmite el relato (como sucedía con el de la rana y el escorpión o el del segador y la serpiente). Hay que tener en cuenta también otras particularidades del texto, que podemos catalogar de episodio fabulístico. (a) En todos los manuscritos que lo recogen aparece la expresión had $z^{e}$ man ('en una ocasión'), frente a las demás anécdotas de LvR 22,4, que no se introducen con indicación ninguna, y frente a las fábulas, que comienzan siempre con la fórmula aramea 'ubda' hawá $b^{e}$... ('érase una vez'). (b) Estamos ante el único ejemplo de LvR 22,4 donde un rabino es descrito como un «observador de la naturaleza», en oposición a los demás sabios, de los que no se menciona ninguna característica especial.

R. Simeón ben Jalafta era un observador de los procesos [de la naturaleza]. Tenía un huerto, en [el que] había un roble ${ }^{25}$; en una ocasión (חד זמן) estaba sentado en él (huerto) [y] vio una abubilla que se construía un nido en él (el roble). Exclamó: «¡No tiene ninguna utilidad este pájaro inmundo en este huerto!». Fue R. Simeón ben Jalafta y demolió aquel nido, [pero] la abubilla fue y lo reparó. Se levantó R. Simeón ben Jalafta y lo demolió [de nuevo], [pero] fue la abubilla y lo reparó [de nuevo]. ¿Qué hizo R. Simeón ben Jalafta? Fue [y] trajo una tabla y la colocó en la superficie de la abertura y colocó en ella un clavo. ¿Qué hizo la abubilla? Fue [y] trajo una hierba y la colocó sobre aquel clavo y lo quemó. ¿Qué hizo R. Simeón ben Jalafta? Exclamó: «Más me valdría esconder esta hierba, no vaya a ser que aprendan los ladrones a hacer[lo] así y destruyan a la gente».

Tanto las fábulas como las anécdotas de los rabinos que hemos visto hasta el momento estaban claramente en conexión con la interpretación midrásica de Qo 5,8 , donde los agentes divinos (los animales o el fémur) habían sido destinados a cumplir una misión. Este episodio fabulístico -y los dos que vienen a continuación-, además de iluminar la moraleja que encierra Qo 5,8 (incluso lo que parece inmundo tiene su razón de ser), puede ser considerado uno de los casos ejemplares que tantas veces nos proporciona la naturaleza y del que se extrae

${ }^{25}$ Ms. de Múnich lee: «Y estaba enseñando debajo de un algarrobo». 
una enseñanza práctica. En el contexto de LvR 22,4 la función del pájaro y la hierba es demostrar a los ladrones cómo expoliar a los hombres, por lo cual el rabino decide esconder la planta.

A pesar de que en la tradición esópica no aparece ninguna historia igual al episodio de R. Simeón ben Jalafta, en varias fábulas se pueden identificar temas parecidos. Por un lado, hay relatos que tratan acerca de la problemática del árbol habitado por los animales y, por otro, encontramos narraciones que ponen de manifiesto el sentimiento de desconfianza o desprecio entre hombres y aves, demostrando en algunos casos el ingenio de éstas sobre los recursos humanos.

Entre las primeras destaca la fábula del árbol sin frutos (Perry 299; Gibbs 463). Este árbol, habitado por gorriones y cigarras, se encontraba en el terreno de un granjero. Como el hombre no sacaba ningún provecho de él, se dispuso a talarlo, pero los animales apelaron a su generosidad para que lo dejara intacto y pudieran seguir viviendo en él. Sus súplicas no sirvieron de nada, pues tomó un hacha y comenzó a cortarlo. Sólo cuando se dio cuenta de que contenía una colmena con rica miel, decidió conservarlo.

Entre las fábulas que se centran en las relaciones de los hombres con los pájaros, varias narran cómo los seres humanos son capaces de acabar con ellos gracias a su imaginación ${ }^{26}$; pero también hay otras donde estos animales hacen gala de una lucidez mayor que la humana. Un caso así es el de las aves que se enternecieron con las lágrimas de un cazador de pájaros, pero uno más sabio se percató de que lloraba sólo para conmoverlos y poder apresarlos, de modo que puso sobre aviso a sus semejantes (Perry 576; Gibbs 297) ${ }^{27}$.

Si bien los relatos difieren bastante del episodio del rabino, podemos observar imágenes en común muy significativas entre las fábulas esópicas y la midrásica: el árbol habitado por animales y situado en un campo privado, la obsesión del hombre por deshacerse de aquellos elementos que no le proporcionan beneficio en sus dominios y el predominio de la inteligencia de un ave sobre la humana.

${ }^{26}$ Por ejemplo: el caso de las grajillas que se comían los frutos del campo de un labriego (Perry 298; GibBs 295), el de la alondra y la trampa del cazador de pájaros (PerRy 193; GibBs 87), el granjero que engañó a los pájaros llamando pan a su honda (PERRY 298; GibBs 295), etc.

27 También podemos citar la historia del cazador de pájaros que iba a recibir una visita y no tenía un animal a quien matar. La perdiz, que era el reclamo para las presas, supo exponer sus argumentos y consiguió salvar su vida, mientras que el gallo, a pesar de ser el pájaro que cantaba las horas, acabó sacrificado (PerRy 361; GibBs 123). 
2.6. La anécdota de la burra de Yannay y la fábula del compañero ciego y del vidente

La hierba que la abubilla utiliza para quemar el clavo es el elemento que enlaza el episodio fabulístico de R. Simeón ben Jalafta con los casos que vienen a continuación. Ahora la hierba tiene las propiedades de quitar y devolver la visión a los animales y a los hombres. En torno a esta temática el Midrás introduce una anécdota relacionada con la burra de R. Yannay (el cual ya aparecía en uno de los episodios sobre la mordedura de una serpiente) y una fábula centrada en dos compañeros que intercambian su situación cuando comen de la hierba: el ciego puede ver y el vidente pierde esta capacidad.

La burra de R. Yannay comió una hierba y se quedó ciega, pero comió [de nuevo de la] hierba y recobró la visión.

Érase una vez (הוה עובדא ב...) dos hombres que estaban subiendo por los caminos de Tiberias, uno era ciego y el otro de [buena] vista, [de manera que] el que podía ver guiaba al [ciego]. Se sentaron a tomar un tentempié en el camino y así sucedió [cuando] comieron de la hierba: el que era ciego recobró la visión y el que podía ver se quedó ciego, y cuando se marcharon de allí el [que había sido] ciego guiaba al [que había podido] ver.

La anécdota, que se recoge también en arameo en QoR 5,5, ofrece sólo un breve sumario sobre lo sucedido con la burra de Yannay. En cambio, la fábula (que ya no tiene conexión con el rabino) está mucho más elaborada: sitúa los hechos en un contexto determinado, caracteriza a los personajes y resuelve la trama con el intercambio de papeles entre ellos. Asimismo, debió de gozar de mucha popularidad, pues ha sido también transmitida por varios de los paralelos de LvR 22,4 (NmR 18,22; QoR 5,5; Tanj Huqqat 1). Pese a las diferencias, los dos relatos se complementan, ya que, además de compartir un mismo tema, ambos presentan una situación excepcional, que provoca un sorprendente contraste entre ellos. Mientras que habitualmente el personaje principal en los episodios es un rabino y los protagonistas de las fábulas los animales, aquí se invierten los papeles: la anécdota trata el caso de la burra de uno de los maestros y el ejemplo fabulístico el de dos hombres.

Entre las fábulas esópicas no existe ninguna historia como la del ciego y su compañero, pero no faltan ni los cuentos sobre dos viajeros que tienen una característica totalmente opuesta o actúan de manera muy diferente ante una situación determinada, ni los de personas invidentes. Por ejemplo, entre los primeros tenemos la fábula de los monos y de los dos hombres, el que mentía siempre y el que siempre decía la verdad (Perry 569; Gibbs 108), y la fábula de los amigos 
que viajaban juntos y se toparon con un oso, uno subiéndose a un árbol y el otro tirándose al suelo haciéndose el muerto (Perry 65; Gibbs 91). Y entre los relatos de invidentes está la fábula del ciego con un sentido del tacto tan magnífico que lo hacía capaz de distinguir cualquier animal que acariciaba (Perry 37; Gibbs 37) ${ }^{28}$.

\subsection{La fábula de los pájaros y la hierba vivificadora y el hombre que le devolvió la vida a un zorro y a un león}

La última fábula de LvR 22,4, también en arameo, es la más elaborada de todas las que hemos visto y tiene como paralelos QoR 5,5 (con el texto completo) y NmR 18,22; Tanj Huqqat 1 (en los que falta parte del pasaje). La historia está en conexión con el anterior relato a través de la hierba curativa, pero ahora ya no tiene la propiedad de devolver la vista, sino de hacer revivir a los muertos.

En los casos anteriores (en los apartados 2.5. y 2.6.) veíamos que, además de la enseñanza vinculada a la interpretación midrásica de Qo 5,8, se podía extraer una segunda lección relacionada con la observación de la naturaleza. Aquí, sin embargo, el texto presenta su propia moraleja al final del pasaje (epimicio), recogiendo un dicho popular.

El relato se compone de varias escenas -quizás de varias fábulas- protagonizadas por distintos personajes: (1) descripción de las circunstancias del personaje humano, (2) la pelea entre dos pájaros, (3) la prueba de revivir a un zorro, (4) la de revivir a un león y la muerte del hombre, (5) la moraleja.

Érase una vez (עובדא הוה ב...) un hombre que subía desde Babilonia ${ }^{29}$ y se sentó a tomar un tentempié por el camino.

Vio a dos pájaros peleando en el camino el uno contra el otro y uno de los dos mató a [su] compañero. Fue el último (el pájaro vivo) y trajo una hierba y la colocó sobre él (el pájaro muerto) y lo devolvió a la vida. Exclamó: «iMás me vale que tome de esta hierba para hacer revivir a los muertos de la tierra de Israel!».

${ }^{28}$ Curiosamente en la literatura india nos ha llegado un cuento sobre dos hombres que viajaban a caballo, de los cuales uno era ciego. Después de pasar la noche en una pradera, el invidente encontró una serpiente helada de frío a la que confundió con una fusta mejor que la suya y decidió quedársela. Al hacerse totalmente de día, el acompañante intentó avisarle de que en la mano llevaba una serpiente, pero éste pensó que intentaba engañarle. Entonces la serpiente se despertó y mordió al ciego causándole la muerte (Burrows DanTON, «The Blind Man and the Snake», recogido en The Baldwin Project).

${ }^{29}$ A la tierra de Israel. 
Mientras subía corriendo vio un zorro muerto tirado en el camino. Exclamó: « ¡Más me vale que lo intente con este zorro!». Entonces colocó (la hierba) sobre él y (el zorro) revivió.

Continuó subiendo hasta que llegó a las colinas de Tiro. Cuando llegó a las colinas de Tiro, vio un león muerto tirado en el camino. Exclamó: «iMás me vale que lo intente con este león!». Entonces colocó sobre él [un poco] de aquella hierba y (el león) revivió. [En ese momento] se levantó y lo devoró.

Esto [confirma] lo que dice la gente (הוא דבירייתא אמרין) : «Vas a hacer el bien a un malo? ¡no hagas el bien a un malo y nada malo te pasará!».

Basta con echar un vistazo a los índices de cualquier colección de fábulas esópicas antiguas o modernas o a los de cuentos de la India para observar la cantidad de historias que tienen como protagonistas a los pájaros, a un zorro o a un león ${ }^{31}$. No obstante, no existe entre los relatos ninguna narración exactamente igual a la que aquí tenemos, donde la aplicación de cierta hierba hace revivir a los tres animales uno tras otro. En cualquier caso, esto no significa que en la base del relato midrásico no se halle ninguno de los motivos de la fabulística más antigua. De hecho, algunos de los autores que se ocuparon de los cuentos de animales en la literatura rabínica observaron que el motivo del león reanimado aparece en los relatos indios antiguos y que después fue recogido también en las colecciones europeas medievales ${ }^{32}$.

En las fábulas esópicas no se encuentra esta imagen del león, pero existe un caso parecido donde un animal ataca al hombre que lo revive y cuya moraleja responde a la misma idea que en la narración midrásica. Se cuenta que un granjero halló una víbora helada de frío y, sintiendo compasión, se la puso en su pecho para reanimarla. Al reaccionar al calor humano mató al granjero, el cual, moribundo, exclamó que hacer el bien a un malvado no trae buenas consecuencias (Perry 176; Gibbs 440) ${ }^{33}$.

${ }^{30}$ Esta expresión sirve para introducir un dicho popular. En el Ms. de Múnich se utiliza el término específico מתלא ('refrán, proverbio').

${ }^{31}$ Sobre el zorro y el león en las fábulas que presenta la literatura rabínica véase SINGER, Animals in Rabbinic Teaching, págs. 50-78 y 138-165.

32 Véase la lista de fábulas de JACOBS, «Aesop's Fables» y SchwarzBaum, The Mishle Shu'alim, pág. 547, n. 5. Una versión de la fábula india se puede consultar en G. L. ChandiRAmani (trad.), Panchatantra. Pandit Vishnu Sharma (Calcuta - Allahabad - Bombay - Delhi 1993), págs. 224-225.

${ }^{33}$ Gibbs cita al respecto el siguiente refrán hallado en el Satiricón de Petronio (Sat. 77): «Estás alimentando una serpiente en tu pecho» (Tu viperam sub ala nutricas). Otro caso interesante es el del perro y el jardinero (PERRY 120; GIBBS 77): un perro cayó en un pozo y el jardinero intentó salvarlo, pero éste le mordió creyendo que quería ahogarlo. 


\subsection{El episodio del hombre aquejado de úlceras y el pozo de Miriam}

El último episodio del párrafo está vinculado, por un lado, a la fábula anterior a través del elemento sanador (allí la hierba y aquí el agua) y, por otro, menciona explícitamente la interpretación midrásica de Qo 5,8, donde ahora son las aguas las que cumplen la misión divina. Este relato conecta directamente con LvR 22,3 y con la historia de Tito y el mosquito del vino. En una de las escenas se dice que, después de saquear el Templo y embarcar camino de Roma, se originó tal tormenta que el propio Tito reconoció el poder divino en las aguas, observando que a través de ellas fueron castigadas las generaciones de malvados (la de Enós, la del diluvio, etc.). En esta ocasión, sin embargo, las aguas no tienen un objetivo punitivo, sino la curación de un hombre aquejado de úlceras que bajaba a bañarse al pozo de Miriam.

El pasaje tiene como paralelos QoR 5,5 y con alguna variante NmR 18,22 y Tanj Huqqat 1, y ha sido transmitido casi todo en hebreo. El episodio, que se introduce con ma aśé, ya no consiste en una anécdota relativa a un rabino, como había sucedido hasta ahora, sino en un ejemplo que sirve para justificar la opinión de un maestro.

Dijo R. Tanjuma: Incluso a través de las aguas el Santo Bendito Sea cumple Su misión.

Había una vez (מעשה ב...) un hombre aquejado de úlceras que bajaba a darse baños en el lago de Tiberias y así sucedió: salió [a la superficie] el pozo de Miriam, (EP añade: se bañó) y se curó. ¿Dónde está el pozo de Miriam?

Dijo R. Jiyya bar Abba: Está escrito: «Se ve sobre la superficie del Yesimón» $(\mathrm{Nm} 21,20)^{34}$, [refiriéndose a] que cualquiera que suba sobre la cima del monte Yesimón verá entonces como un pequeño coladero en el mar de Tiberias. Éste es el pozo de Miriam.

Dijo R. Yojanán ben Marya: Nuestros Rabbíes hicieron el cálculo y éste (el pozo) está justo enfrente de la puerta central de la antigua sinagoga de Seringit ${ }^{35}$.

Es evidente que ya no se trata de una fábula como las anteriores, ni tampoco de una anécdota relacionada con un rabino. El texto nos lo indica tanto por el propio contenido como a nivel formal: (a) hay un predominio del hebreo frente a los relatos anteriores que se han transmitido principalmente en arameo; (b) en todos los manuscritos este ejemplo se introduce con ma'aśé $b^{e}$ (heb.) en lugar de 'ubda' hawá $b^{e}$ (aram.).

34 Yešimon significa 'desierto' y en el TM se refiere a una zona desértica de Judá al noreste del Mar Muerto. En NmR 19,26 se explica este versículo: «lo que puede ser visto en Yesimón (en el desierto) es el pozo del Mar de Tiberias».

${ }^{35}$ Posiblemente Serungaya o Serungin, cerca de Tiberias. EP lee: «De Tiberias». 
No obstante, se podría alegar al respecto que ambas fórmulas son equivalentes y que lo esperado sería la expresión con ma aséé, dado que la mayoría del pasaje se ha transmitido en hebreo. Sin embargo, una de las partes del texto que está en arameo se halla precisamente en la historia del hombre aquejado de úlceras. Así pues, resulta bastante significativo el uso de ma'aśé para marcar este cambio en la narración, sobre todo si tenemos en cuenta cómo prosigue. El interés de los rabinos ya no se centra en las fábulas de animales o en las anécdotas de los maestros, sino en torno al pozo de Miriam; después el Midrás continúa en LvR 22,5 con la cuestión de los sacrificios en tiempos del Tabernáculo, finalizando con la cita de Lv 17,3-4 (el versículo que comenta la parašá) y cerrando la sección vinculada a Qo 5,8.

\section{Contexto y estructura Del PASAJE: COMbinación DE FÁbUlas y ANÉCDOTAS DE RABINOS EN LvR 22,4}

Sin detenernos a estudiar en profundidad la estructura del pasaje, dos apreciaciones pueden sernos de gran ayuda para entender (a) por qué encontramos fábulas precisamente en LvR 22,4 y (b) cómo consigue el Midrás articular estas narraciones con las anécdotas de rabinos.

a. Las fábulas y las anécdotas se han insertado en el texto que comprende LvR 22,1-5. Como habíamos visto, la parašá se ocupa de Lv 17,3 en conexión con Qo 5,8, es decir, un versículo acerca de los sacrificios, con otro sobre lo superfluo que existe en el mundo. De lo que se considera superfluo se exponen varios ejemplos (en LvR 22,1), entre los que se menciona a los insectos (LvR 22,2) y después a los animales (en LvR 22,3), que en LvR 22,4 pasan a ser protagonistas de las fábulas o están relacionados con las anécdotas de los rabinos. En conexión con el mosquito se narra (al final de LvR 22,3) la historia de Tito y el episodio de la tempestad, donde él mismo reconoce el poder divino en las aguas. Seguidamente, indicando que se trata de «otra interpretación» de Qo 5,8, son introducidos los relatos (ya en LvR 22,4). A su vez, en la última de las historias de LvR 22,4, que ya no pertenece al género de la fábula y que tampoco es una anécdota, el Midrás vuelve a aludir a las aguas y, a continuación (en LvR 22,5), retoma el tema de los sacrificios y acaba con la cita de Lv 17,3. Así pues, es el propio contexto el que predispone la inclusión de este tipo de narraciones y también el que permite retomar de nuevo la interpretación midrásica del versículo sobre los sacrificios (Lv 17,3).

b. Respecto a la sección de LvR 22,4 propiamente, el siguiente cuadro nos ayudará a entender cómo el Midrás combina de forma armoniosa las fábulas con las anécdotas a través de los elementos conectores y cómo introduce las historias diferenciando a su vez un género de otro. 


\begin{tabular}{|c|c|c|c|c|}
\hline RELATOS & TIPO DE RELATO & $\begin{array}{c}\text { FÓRMULA } \\
\text { INTRODUCTORIA }\end{array}$ & $\begin{array}{l}\text { ELEMENTO } \\
\text { CONECTOR }\end{array}$ & $\begin{array}{l}\text { MORALEJA / } \\
\text { ENSEÑANZA }\end{array}$ \\
\hline $\begin{array}{c}\text { La rana } \\
\text { y el escorpión }\end{array}$ & Fábula & עובדאa & - Misión divina $\downarrow$ & Qo 5,8 \\
\hline $\begin{array}{l}\text { El segador y la } \\
\text { serpiente }\end{array}$ & Fábula & עובדא a & $\begin{array}{l}\text { - Misión divina } \uparrow \\
\text { - Serpiente } \downarrow\end{array}$ & Qo 5,8 \\
\hline $\begin{array}{l}\text { R. Yannay }{ }^{b} y \\
\text { la mordedura de } \\
\text { serpiente }\end{array}$ & Anécdota & Nombre del rabino & $\begin{array}{l}\text { - Misión divina } \uparrow \\
\text { - Serpiente } \uparrow\end{array}$ & Qo 5,8 \\
\hline $\begin{array}{l}\text { R. Lazar y la } \\
\text { mordedura de } \\
\text { serpiente }\end{array}$ & Anécdota & Nombre del rabino & $\begin{array}{l}\text { - Misión divina } \uparrow \\
\text { - Serpiente } \uparrow \\
\text { - Romano } \downarrow\end{array}$ & Qo 5,8 \\
\hline $\begin{array}{c}\text { R. Yisjaq ben } \\
\text { Elazar, el fémur } \\
\text { y el emisario } \\
\text { imperial }\end{array}$ & Anécdota & Nombre del rabino & $\begin{array}{l}\text { - Misión divina } \uparrow \\
\text { - Romano } \uparrow\end{array}$ & Qo 5,8 \\
\hline $\begin{array}{c}\text { El huerto de } \\
\text { R. Simeón ben } \\
\text { Jalafta, la hierba } \\
\text { y la abubilla }{ }^{c}\end{array}$ & $\begin{array}{l}\text { Episodio fabulístico } \\
\text { (anécdota + fábula) }\end{array}$ & $\begin{array}{c}\text { Nombre del rabino } \\
+ \\
+ \\
\text { חדמן }\end{array}$ & $\begin{array}{l}\text { - Observación } \\
\text { de la naturaleza } \\
\uparrow(?) \\
\text { - }(\text { Pájaro } \downarrow)^{\mathrm{d}} \\
\text { - Hierba } \downarrow \\
\end{array}$ & $\begin{array}{c}(\text { Qo 5,8) } \\
\text { Naturaleza como } \\
\text { maestra (?) }\end{array}$ \\
\hline $\begin{array}{c}\text { La burra de } \\
\text { Yannay } \\
\& \\
\text { el compañero } \\
\text { ciego y el } \\
\text { vidente }\end{array}$ & $\begin{array}{c}\text { Anécdota } \\
+ \\
\text { fábula }\end{array}$ & $\begin{array}{c}\text { Nombre del rabino } \\
+ \\
\text { עובדא }\end{array}$ & $\begin{array}{r}- \text { Hierba } \uparrow \\
\text { - elemento } \\
\text { sanador } \downarrow\end{array}$ & $\begin{array}{l}\text { (Qo 5,8) } \\
\text { Lo que puede sanar, } \\
\text { puede dañar (?) }\end{array}$ \\
\hline $\begin{array}{c}\text { Los pájaros } \\
\text { y la hierba } \\
\text { vivificadora } \\
\& \\
\text { el hombre que le } \\
\text { devolvió la vida } \\
\text { a un zorro y a un } \\
\text { león }\end{array}$ & $\begin{array}{c}\text { Fábula } \\
\text { (compuesta por } \\
\text { varias escenas o } \\
\text { fábulas) }\end{array}$ & עובדא & $\begin{array}{l}\text { - Hierba } \uparrow \\
\text { - elemento } \\
\quad \text { sanador } \uparrow \\
\text { - }(\text { Los pájaros } \uparrow)\end{array}$ & $\begin{array}{c}\text { הוא דבירייתא אמרין } \\
\text { «No hagas el bien a } \\
\text { un malvado»e }\end{array}$ \\
\hline $\begin{array}{c}\text { El hombre } \\
\text { aquejado de } \\
\text { úlceras y el pozo } \\
\text { de Miriam }\end{array}$ & $\begin{array}{c}\text { Episodio } \\
\text { (no es una anécdota } \\
\text { ni una fábula) }\end{array}$ & מעשה - - מעה & $\begin{array}{l}\text { - Elemento } \\
\quad \text { sanador } \uparrow \\
\text { - Misión divina } \\
\text { - Las aguas }{ }^{\mathrm{f}} \\
\end{array}$ & Qo 5,8 \\
\hline \multicolumn{5}{|c|}{$\begin{array}{l}\text { a En el ms. de Múnich: מעשה. } \\
\text { b. Rannay también aparece después en otro episodio. Su participación puede ser otro elemento conector entre } \\
\text { las historias. } \\
\text { c Este relato está vinculado a los anteriores (contexto de la naturaleza), pero se aprecia una ruptura con ellos en la } \\
\text { forma (mezcla entre fábula y anécdota) y en la temática (no hay un elemento de unión directo con los otros casos). } \\
\text { d El pájaro vuelve a aparecer no en el relato contiguo, sino en el siguiente a éste. } \\
\text { e En el ms. de Múnich: מתלא } \\
{ }^{\text {f }} \text { Como en los primeros relatos. } \\
\text { g Las aguas en conexión con el episodio de Tito y la tempestad en LvR 22,3. }\end{array}$} \\
\hline
\end{tabular}




\section{CONCLUSIONES}

El texto de LvR 22,4 es un magnífico ejemplo de cómo la literatura rabínica combina fábulas y anécdotas de rabinos para justificar la interpretación de un versículo en un contexto determinado. Las conclusiones que se extraigan del presente estudio podrán servirnos como guía para abordar otros pasajes donde se halle este tipo de relatos en el Midrás y el Talmud, en especial donde aparezcan pequeñas colecciones de fábulas.

a. No es posible afirmar con toda seguridad si el origen de varias de las fábulas de LvR 22,4 se encuentra en la tradición esópica. No obstante, muchas de las imágenes se observan también en las grandes colecciones de época helenística-romana que nos han llegado y/o en las fábulas de la India, de las que también bebieron las composiciones esópicas. Hay que tener en cuenta que las colecciones más antiguas vinculadas a la autoría de Esopo se perdieron, lo que todavía abre más el abanico de posibilidades.

b. El carácter popular de este género jugó un papel determinante en la transmisión oral de las fábulas de un pueblo a otro, a pesar de la existencia de las grandes colecciones. Además, muchas de ellas sufrieron reelaboraciones con la finalidad de hacerlas encajar mejor en los contextos particulares y dar respuesta a problemas concretos de una sociedad específica.

c. En el Talmud y en el Midrás hay casos de fábulas que son un paralelo claro de los relatos esópicos (a excepción de algunos elementos o de la finalidad expuesta en la moraleja). Pero también se encuentran fábulas que no responden a una narración esópica, sino a un motivo esópico, como por ejemplo: el uso de una imagen en una situación concreta, la misma relación entre los personajes, etc. De hecho, en LvR 22,4 no podemos hablar de «fábulas esópicas», sino de «motivos esópicos» entre las fábulas rabínicas.

d. La aparición de fábulas en el Midrás o el Talmud se debe a un determinado contexto. Normalmente se trata de temas vinculados a la observación de la naturaleza y sobre todo del mundo animal, como sucede con nuestro pasaje.

e. La literatura rabínica reúne las condiciones necesarias para dar cabida a la fábula a través de las parábolas y los casos particulares con los que se justifica una opinión o se deduce una norma. Así, LvR 22,4 se sirve de los últimos para introducir la mayoría de las fábulas.

f. Además, esta literatura desarrolló los recursos suficientes para diferenciar un género de otro dentro del esquema de los casos particulares. Según 
hemos observado, en LvR 22,4 las fábulas se anuncian con la fórmula aramea עובדא הוה ב..., las anécdotas con el nombre del rabino sin indicación ninguna, el episodio fabulístico (a medio camino entre la fábula y la anécdota) con חד זמן y, cuando se retoma la interpretación midrásica del versículo, se incluye un episodio de transición marcado con la expresión hebrea מעשה ב... También es un indicio importante el uso de una lengua u otra: la sección de fábulas y anécdotas se ha transmitido casi toda en arameo frente a la última historia que se recoge en hebreo. Esto no significa que, cada vez que nos encontremos ante un párrafo similar, siempre se utilicen las mismas fórmulas y siempre se transmita en arameo. Únicamente podemos afirmar que la literatura rabínica disponía de una considerable riqueza para hacerle notar al receptor los matices entre los géneros.

g. Las fábulas combinan perfectamente con las anécdotas sobre rabinos gracias a que comparten un mismo contexto y una misma temática y a que se relacionan unas con otras a través de los elementos en común: personajes, situaciones, objetivos, enseñanza que se desprende del texto, etc.

h. La interpretación rabínica de un versículo bíblico (en este caso de Qo 5,8 ) puede hacer la función de moraleja de una o más fábulas y, a su vez, responder a la enseñanza que se extrae de los casos particulares.

i. La inclusión de fábulas en pasajes como éste se debió con toda seguridad a la apertura del Midrás -y del Talmud- para absorber la sabiduría popular y desarrollarla como parte de su corpus temático. De hecho, si hubiera forma de comprobar que muchas de las historias se conocían en el entorno rabínico tal y como nos han llegado en las colecciones esópicas, seríamos mucho más conscientes de la genialidad del Midrás al modificar algunos de sus contenidos y/o a diseñar un final diferente al habitual que causara un gran impacto en el receptor ${ }^{36}$.

Recibido: $14 / 04 / 2009$

Aceptado: 01/07/2009

${ }^{36}$ Este trabajo se ha realizado con el apoyo de un Contrato de Investigación para Doctores de la Universidad de Granada y en el marco del Proyecto de Investigación: Lengua y literatura del Judaísmo Clásico: Rabínico y Medieval (HUM 2006-02495/FILO). Quiero agradecerles a los profesores Dr. Luis F. Girón Blanc (UCM) y Dr. Günter Stemberger (Universidad de Viena) sus valiosísimas sugerencias. Una breve presentación de esta investigación se expuso en la Reunión Anual de la Asociación Española de Estudios Hebreos y Judíos (AEEHJ), celebrada en Girona Besalú, los días 29-31 de mayo de 2008. 